to speech therapy nor a panacea for a deficiency in NHS provision.

We are grateful for the co-operation of the many participants in the project; for help in the preparation of this paper we thank particularly Mrs S Clark, Dr R G Cooper, Miss J Mitchell, and Professor D A Shaw.

\section{References}

1 Geriatrics Committee Working Group on Strokes, Report. Royal College of Physicians, London, 1974.

${ }^{2}$ Chest, Heart and Stroke fournal, 1976, 1, 25.

3 Griffith, V E, A Stroke in the Family. London, Wildwood House, 1975.
${ }^{4}$ Griffith, V E, British Medical fournal, 1975, 3, 633.

${ }^{5}$ Goodglass, H, and Kaplan, E, Assessment of Aphasia and Related Disorders. Philadelphia, Lea and Febiger, 1972.

6 Taylor, M, Archives of Physical Medicine and Rehabilitation, 1965, 45, 101. W 7 Trower, P, Bryant, B, and Argyle, M, Social Skills and Mental Health, pp 139, 146. London, Methuen, 1978.

${ }^{8}$ Reinvang, I, Scandinavian fournal of Rehabilitation Medicine, 1969, 1, 112.

${ }^{9}$ Darvill, G, Bargain or Barricade? Berkhamsted, Volunteer Centre, 1975.

${ }^{10}$ Volunteer Involvement in the National Health Service. Berkhamsted, Volunteer Centre, 1976

11 Darvill, G, Age Concern Today, 1977, 15 November, p 7.

12 Broida, H, Archives of Physical Medicine and Rehabilitation, 1977, 58, 248.

13 Hagen, C, Archives of Physical Medicine and Rehabilitation, 1973, 54, 454.

14 Basso, A, Faglioni, P, and Vignolo, L A, Revue Neurologique, 1975, 131, 607.

(Accepted 11 September 1978)

\title{
Decreased first-pass metabolism of labetalol in chronic liver disease
}

\author{
M HOMEIDA, L JACKSON, C J C ROBERTS
}

British Medical fournal, 1978, 2, 1048-1050

\section{Summary and conclusions}

The effect of chronic liver disease on the rate of elimination and extent of "first-pass" metabolism of labetalol was studied. Pharmacokinetic measurements were made after both oral and intravenous administration to seven healthy subjects and to 10 patients with chronic liver disease. Plasma half life was similar in the two groups. Plasma concentrations were considerably higher in the patients than in the healthy subjects after oral administration but similar after intravenous injection. Thus the bioavailability of labetalol was increased in liver disease due to reduced first-pass metabolism. Bioavailability in the group of patients correlated negatively with serum albumin concentration.

There were falls in supine heart rate and blood pressure which tended to be greater after oral administration in the patients with liver disease, suggesting an exaggerated response related to the increased bioavailability. Oral dosage requirements of labetalol and possibly other drugs susceptible to first-pass metabolism are reduced in the presence of liver disease.

\section{Introduction}

Labetalol is a new antihypertensive agent with both $\alpha$ - and $\beta$ adrenoreceptor blocking properties. ${ }^{1}$ In common with many beta-blockers it is extensively metabolised in the liver, less than $5 \%$ being excreted unchanged in the urine. ${ }^{2}$

Reduced bioavailability after oral administration due to hepatic "first-pass" metabolism has been found for propranolol, ${ }^{3}$ oxprenolol, ${ }^{4}$ alprenolol, ${ }^{5}$ and metoprolol ${ }^{6}$ as well as for many other drugs for which hepatic extraction is high. Variability in the extent of first-pass metabolism between individuals is wide ${ }^{7}$

\footnotetext{
Departments of Medicine and Pharmacology, University of Bristol, Bristol

M HOMEIDA, MB, MRCP, honorary senior registrar

L JACKSON, MB, MRCP, honorary registrar

C J C ROBERTS, MB, MRCP, lecturer
}

and accounts for some of the variation in dose requirements of propranolol. ${ }^{8}$ Metabolic studies of labetalol in animals and man ${ }^{2}$ and a study in a single individual when plasma concentrations after oral and intravenous administration were measured ${ }^{9}$ suggested that first-pass metabolism of labetalol was considerable and its systemic bioavailability $40 \%$ or less.

In chronic liver disease drug metabolising capacity is decreased. The elimination half lives of antipyrine, ${ }^{10-12}$ propranolol, ${ }^{13}$ and phenylbutazone, ${ }^{14}$ among others, are prolonged in chronic liver disease. The effect of chronic liver disease on first-pass metabolism has hitherto been studied only for propranolol, ${ }^{15}$ when increased bioavailability was found.

This study was set up to compare the rates of elimination and extent of first-pass metabolism of labetalol in patients with chronic liver disease with those of healthy individuals.

\section{Patients and methods}

Ten patients with histologically proved chronic liver disease (table I) and seven normal controls were studied in Bristol Royal Infirmary. The controls were aged 22 to 42 years and two of them were women.

No one was taking drugs that interfered with the assay of labetalol $N$ or influenced drug metabolism, and none of the patients had had surgical portacaval anastomoses.

TABLE I-Patient characteristics

\begin{tabular}{|c|c|c|c|c|c|c|c|}
\hline $\begin{array}{l}\text { Case } \\
\text { No }\end{array}$ & $\begin{array}{l}\text { Age } \\
\text { and } \\
\text { sex }\end{array}$ & $\underset{(\mathrm{g} / 1)}{\operatorname{Serum}}$ & $\begin{array}{r}\text { Bilirubin } \\
(\mu \mathrm{mol} / \mathrm{l})\end{array}$ & $\begin{array}{c}\text { Aspartate } \\
\text { amino- } \\
\text { trans- } \\
\text { ferase } \\
(\mathrm{IU} / \mathbf{l})\end{array}$ & $\begin{array}{c}\text { Alkaline } \\
\text { phos- } \\
\text { phatase } \\
\text { (KA } \\
\text { units) }\end{array}$ & Diagnosis & $\begin{array}{l}\text { Oedema } \\
\text { and } \\
\text { ascites }\end{array}$ \\
\hline 1 & $50 \mathrm{M}$ & 46 & 14 & 28 & 7 & Alcoholic & No \\
\hline 2 & $65 \mathrm{M}$ & 34 & 24 & 32 & 51 & Cirrhosis & No \\
\hline 3 & $53 \mathrm{~F}$ & 40 & 70 & 55 & & $\begin{array}{l}\text { Primary } \\
\text { biliary } \\
\text { cirrhosis }\end{array}$ & No \\
\hline 4 & $68 \mathrm{M}$ & 41 & 12 & 14 & 14 & $\begin{array}{l}\text { Alcoholic } \\
\text { cirrhosic }\end{array}$ & No \\
\hline 5 & $67 \mathrm{M}$ & 43 & 33 & 12 & 10 & Alcoholic & No \\
\hline $\begin{array}{l}6 \\
7\end{array}$ & $\begin{array}{l}57 \mathrm{M} \\
31 \mathrm{~F}\end{array}$ & $\begin{array}{l}40 \\
27\end{array}$ & $\begin{array}{l}14 \\
48\end{array}$ & $\begin{array}{r}16 \\
149\end{array}$ & $\begin{array}{l}12 \\
20\end{array}$ & $\begin{array}{l}\text { Cirrhosis } \\
\text { Chronic } \\
\text { active }\end{array}$ & $\begin{array}{l}\text { Yes } \\
\text { No }\end{array}$ \\
\hline 8 & $65 \mathrm{~F}$ & 26 & 8 & 16 & 12 & $\begin{array}{l}\text { hepatitis } \\
\text { Alcoholic }\end{array}$ & Yes \\
\hline 9 & $70 \mathrm{M}$ & 39 & 9 & 8 & 9 & $\begin{array}{l}\text { cirroosis } \\
\text { Alcoholic }\end{array}$ & No \\
\hline 10 & $51 \mathrm{M}$ & 29 & 60 & 34 & 18 & $\begin{array}{l}\text { cirrhosis } \\
\text { Cirrhosis }\end{array}$ & No \\
\hline
\end{tabular}


All subjects were studied supine after an overnight fast on two occasions separated by at least one week. After withdrawal of venous blood and measurement of resting blood pressure and heart rate labetalol was administered either orally or intravenously. The intravenous dose was always $0.5 \mathrm{mg} / \mathrm{kg}$ body weight. The oral dose was $100 \mathrm{mg}$ in the early part of the study, but when it became clear that this dose did not cause untoward effects in patients it was increased to $200 \mathrm{mg}$. After drug administration venous blood samples were drawn at 10, 20,30,40,50,60,90,120,180, 240,300, and 360 minutes. Supine pulse and blood pressure were recorded at the time of blood sampling.

Plasma was immediately separated from blood samples and stored at $-20^{\circ}$ for future analysis. Plasma labetalol levels were assayed at Allen and Hanburys Research Ltd using the method of Martin et al. ${ }^{2}$

\section{CALCULATIONS}

Plasma half life was calculated from least squares linear regression analysis of the terminal exponential of the log plasma concentration time profile.

The area under the plasma concentration-time profile (AUC) was calculated as follows: the area up to the end of sampling (A) was calculated using the trapezoidal rule; subsequent area extrapolated
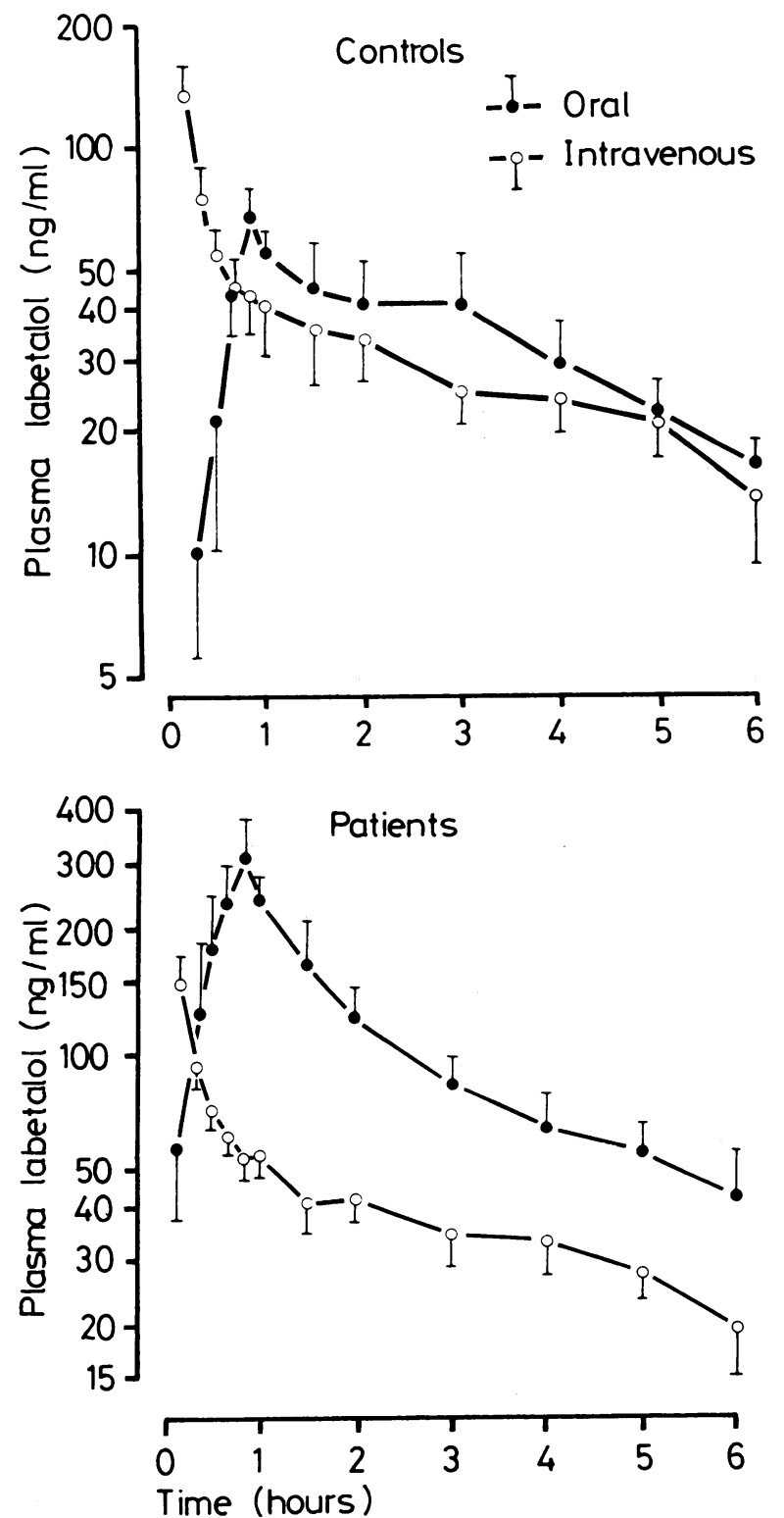

FIG 1-Mean ( \pm SE of mean) labetalol concentrations after oral and intravenous administration in seven normal healthy subjects and 10 patients with chronic liver disease. to infinity (B) was calculated from regression analysis of the terminal $\log$ concentration-time slope: the total area was the sum of $\mathrm{A}+\mathrm{B}$.

Volume of distribution of labetalol was calculated from the data following the intravenous (IV) administration as:

$$
\frac{\text { Dose IV }}{\mathrm{C} \beta, 0}
$$

where dose IV was the dose given and $C \beta, 0$ was the plasma concentration of labetalol at time zero derived from back extrapolation of the termiral exponential of the log concentration-time profile. Systemic bioavailability was calculated as:

$$
\frac{\text { AUC oral }}{\text { AUC IV }} \times \frac{\text { Dose IV }}{\text { Dose oral }}
$$

Student's $t$ test was used for statistical analysis.

\section{Results}

No serious adverse effects from the administration of labetalol occurred. Two normal subjects and one patient complained of transient tingling in the scalp after oral administration.

The doses of labetalol given to both groups were similar. The mean intravenous dose ( \pm SE of mean) was $38 \pm 3 \mathrm{mg}$ for the patients and $41 \pm 7 \mathrm{mg}$ for the controls. Four patients and four controls received $100 \mathrm{mg}$ by mouth and six patients and three controls received $200 \mathrm{mg}$ by mouth. (The mean oral dose for the patients was therefore $160 \mathrm{mg}$ and for the volunteers $143 \mathrm{mg}$.) Body weights were similar in the two groups: $74 \cdot 6 \pm 4 \cdot 8 \mathrm{~kg}$ for the patients and $71 \cdot 4 \pm 3.3 \mathrm{~kg}$ for the healthy subjects.

Composite drug concentrations against time plots are shown in fig 1. The times to peak plasma concentration after oral administration were similar for both groups but the plasma concentrations were considerably higher in the patients. After intravenous administration the biexponential decay was similar in both groups.

The results of the pharmacokinetic measurements are shown in table II. There was no difference between patients and normal subjects in the half life of labetalol after either oral or intravenous administration. The volume of distribution was significantly smaller in the patients. The area under the plasma concentration-time profile was about three times greater in the patients than in the controls after oral administration but was similar after intravenous administration. Systemic bioavailability of labetalol in the patients was about twice that in the controls. Within the healthy subjects there was a $2 \cdot 5$-fold range in bioavailability and within the patients a $2 \cdot 4$-fold range.

A significant negative correlation was found between the serum albumin concentration and systemic bioavailability of labetalol in the patients with liver disease (fig 2).

In most patients and normal subjects supine heart rate and systolic and diastolic blood pressure fell slightly (table III). Maximum falls

TABLE II-Pharmacokinetics of labetalol in seven normal subjects and 10

\begin{tabular}{|c|c|c|c|c|c|c|}
\hline & \multicolumn{2}{|c|}{$\underset{(\min )}{\text { Plasma half life }}$} & \multirow{2}{*}{$\begin{array}{l}\text { Volume of } \\
\text { distribution } \\
\text { (1) }\end{array}$} & \multicolumn{2}{|c|}{$\begin{array}{l}\text { Area under plasma } \\
\text { concentration-time } \\
\text { profile }(\mathrm{ng} / \mathrm{ml} \mathrm{min})\end{array}$} & \multirow{2}{*}{$\begin{array}{c}\text { Systemic } \\
\text { bioavail- } \\
\text { ability } \\
\left(\begin{array}{l}0 \\
0\end{array}\right)\end{array}$} \\
\hline & Oral & Intravenous & & Oral & Intravenous & \\
\hline Controls & $154 \pm 33$ & $187 \pm 26$ & $805 \pm 91$ & $16002 \pm$ & $14986 \pm$ & $33 \pm 3$ \\
\hline Patients & $156 \pm 22$ & $170 \pm 24$ & $526 \pm 31$ & $\begin{array}{c}47640 \text { t. } \\
9040\end{array}$ & $\begin{array}{r}18646 \pm \\
2788\end{array}$ & $63 \pm 7$ \\
\hline$P$ value & NS & NS & $<0.05$ & $<0.01$ & NS & $<0.01$ \\
\hline
\end{tabular}
patients with chronic liver disease

NS $=$ Not significant.

TABLE III-Pharmacodynamic measurements after oral and intravenous administration of labetalol in seven normal subjects and 10 patients with chronic liver

\begin{tabular}{|c|c|c|c|c|c|c|}
\hline & \multicolumn{2}{|c|}{$\begin{array}{l}\text { Mean fall in } \\
\text { heart rate } \\
\text { (beats/min) }\end{array}$} & \multicolumn{2}{|c|}{$\begin{array}{l}\text { Mean fall in supine } \\
\text { diastolic blood } \\
\text { pressure } \\
(\mathrm{mm} \mathrm{Hg})\end{array}$} & \multicolumn{2}{|c|}{$\begin{array}{l}\text { Mean fall in supine } \\
\text { systolic blood } \\
\text { pressure } \\
(\mathrm{mm} \mathrm{Hg})\end{array}$} \\
\hline & Oral & Intravenous & Oral & Intravenous & Oral & Intravenous \\
\hline $\begin{array}{l}\text { Controls.. } \\
\text { Patients } \ldots \\
\text { P } \quad .\end{array}$ & $\begin{array}{r}2.4+1.1 \\
8 \cdot 2+1.9 \\
<0.025\end{array}$ & $\begin{array}{c}6 \cdot 4 \pm 0.9 \\
7.5 \pm 2 \cdot 8 \\
\mathrm{NS}\end{array}$ & $\begin{array}{c}2.7 \pm 1.9 \\
9.2 \pm 2.9 \\
\geq 0.05 \\
<0.1\end{array}$ & $\begin{array}{c}7 \cdot 4+2 \cdot 7 \\
5 \cdot 4+2 \cdot 3 \\
\mathrm{NS}\end{array}$ & $\begin{array}{c}2.6 \pm 1.8 \\
10.5 \pm 4.9 \\
\text { NS }\end{array}$ & $\begin{array}{l}5 \cdot 4 \pm 2 \cdot 6 \\
8 \cdot 5 \pm 3 \cdot n \\
\text { NS }\end{array}$ \\
\hline
\end{tabular}
disease 
occurred at 60 minutes after drug administration either orally or intravenously and returned towards baseline over the subsequent five hours. The fall in heart rate and blood pressure was greater in the patients with liver disease than in the controls after oral administration but similar after intravenous administration.

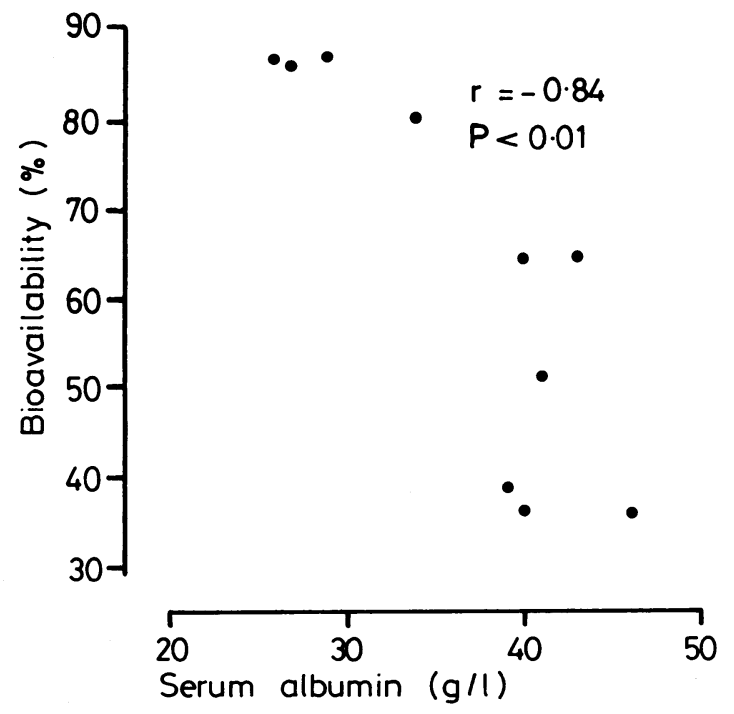

FIG 2-Correlation between serum albumin concentration and systemic bioavailability of labetalol in 10 patients with chronic liver disease.

\section{Discussion}

This study has shown that chronic liver disease decreases the extent of first-pass metabolism of labetalol. The measurements of elimination kinetics in the healthy subjects in this study are consistent with findings with labetalol ${ }^{2}$ and with other lipidsoluble beta-blockers. ${ }^{16}$ The large volume of distribution was to be expected, as only about half the labetalol is bound to plasma proteins. ${ }^{2}$ The diminished volume of distribution in the patients with liver disease despite similar body weights to those of the healthy volunteers probably reflected altered body composition. The finding of a similar half life of labetalol in chronic liver disease was not expected but might have been due partly to the reduced volume of distribution, which would have tended to shorten the half life.

Clinically the most important observation was the greatly increased bioavailability of labetalol found in the patients with chronic liver disease. We used the usual calculation of bioavailability, ${ }^{17}$ but this depends on the assumption that kinetics are independent of dose. Proportionality between the oral dose and area under the plasma concentration-time profile previously described for labetalol ${ }^{2}$ suggests that the kinetics of labetalol are not dose dependent and that our calculation of bioavailability was valid.

Our data do not allow an interpretation of the exact mechanism of the altered bioavailability. In normal people absorption of labetalol is complete, so that metabolism in the gut wall and in the liver are implicated. ${ }^{2}$ In patients with chronic liver disease the drug metabolising capacity of the liver is reduced because of decreased microsomal enzyme content or activity. ${ }^{10-12}$ Thus impairment of drug metabolising enzyme systems might account for the decreased first-pass metabolism observed. A further factor in patients with liver disease is the presence of portosystemic shunts. ${ }^{18}$ It has been estimated that as much as $60^{\circ}{ }_{0}$ of portal venous blood flow may be directed to the systemic circulation in severe liver disease, ${ }^{19}$ and propranolol has been shown to be fully bioavailable in patients who have undergone surgical portosystemic anastomoses. ${ }^{3}$ We excluded patients who had had portocaval anastomoses, but many of our patients had decompensated liver disease in which intrahepatic and extrahepatic portosystemic shunting would be expected. Therefore this probably also contributed to the decreased first-pass metabolism of labetalol.

Our results also provide evidence of considerable interindividual variability in the extent of first-pass metabolism of labetalol. The $2 \cdot 5$-fold range in bioavailability found in the normal subjects is similar to the 3-fold range for propranolol. ${ }^{8}$ In chronic liver disease serum albumin concentrations can predict the prolongation of half life of antipyrine, ${ }^{11}$ propranolol, ${ }^{13}$ and phenylbutazone. ${ }^{14}$ The negative correlation between serum albumin concentration and bioavailability of labetalol in the patients with liver disease in this study suggests that serum albumin may also predict the extent of first-pass metabolism. No inference can be drawn from this correlation as to the mechanism of the altered bioavailability of labetalol in liver disease.

Although our study was not primarily designed to examine the actions of labetalol, pulse and blood pressure were monitored during all experiments. The differences in these observations between the two groups suggest a relationship between drug concentrations and response. Such a relationship has been described for several beta-blockers ${ }^{15}$ and labetalol. ${ }^{20}$ In the present study the extent of the falls in heart rate and blood pressure was similar in both groups after intravenous administration, when plasma levels of labetalol were also similar, but was greater in the patients after oral administration, when plasma concentrations were higher. The nature and time course of the changes observed in the healthy subjects are consistent with the results of studies in hypertensive patients. ${ }^{21}{ }^{22}$

This study has elucidated the pharmacokinetic characteristics of labetalol in patients with chronic liver disease and has provided evidence for caution in the use of the drug in such patients. A wider implication is that oral dosage requirements of drugs which undergo first-pass metabolism may be considerably reduced in chronic liver disease.

We are grateful to Professor A E Read for permission to study patients under his care; Mr R E Bland for assaying the plasma labetalol concentrations; and $\operatorname{Dr}$ M D B Stephens and colleagues at Allen and Hanburys Research Ltd for helpful advice and financial support.

\section{References}

${ }^{1}$ Farmer, J B, et al, British fournal of Pharmacology, 1972, 45, 660 .

${ }^{2}$ Martin, L E, Hopkins, R, and Bland, R E, British fournal of Clinical Pharmacology, 1976, 3, suppl No 3, p 695.

3 Shand, D G, and Rangno, R E, Pharmacology, 1972, 7, 159.

${ }^{4}$ Reiss, W, et al, Postgraduate Medical fournal, 1970, 46, November suppl, p 32 .

5 Ablad, B, et al, Life Science, 1974, 14, 693.

6 Regardh, C G, et al, Acta Pharmacologica et Toxicologica, 1975, 36, suppl No $V, p 45$.

${ }^{7}$ Shand, D G, Drugs, 1974, 7, 39.

${ }^{8}$ Kornhauser, D M, et al, Clinical Pharmacology and Therapeutics, 1978, 23, 165

${ }^{9}$ Breckenridge, A M, et al, British fournal of Clinical Pharmacology, 1977, 4, 388.

10 Halliwell, M, Homeida, M, and Roberts, C J C, British fournal of Clinical Pharmacology, 1977, 4, 393.

11 Branch, R A, Herbert, C M, and Read, A E, Gut, 1973, 14, 569.

12 Andreasen, P B, and Griesen, G, European fournal of Clinical Investigation, 1976, 6, 21.

${ }^{13}$ Branch, R A, James, J, and Read, A E, British fourn l of Clinical Pharmacology, 1976, 3, 243.

${ }^{14}$ Levi, A J, Sherlock, S, and Walker, D, Lancet, 1968, 1, 1275

15 Branch, R A, et al, British fournal of Clinical Pharmacology, 1977, 4, 630.

16 Johnssen, G, and Regardh, C G, Clinical Pharmacokinetics, 1976, 1, 223.

17 Ehrnebo, M, Boreus, L O, and Lenroth, U, Clinical Pharmacology and Therapeutics, 1977, 22, 888.

18 Branch, R A, and Shand, D G, Clinical Pharmacokinetics, 1976, 1, 264.

29 Groszmann, R, et al, American fournal of Medicine, 1972, 53, 715.

${ }^{10}$ Richards, D A, et al, European fournal of Clinical Pharmacology, 1977, 11, 85.

${ }^{21}$ Koch, G, British Fournal of Clinical Pharmacology, 1976, 3, suppl No 3, p 729 .

22 Joekes, A M, and Thompson, F D, British fournal of Clinical Pharmacology, $1976,3,789$.

(Accepted 22 August 1978) 